\title{
PEDIATRIC AND ADOLESCENT POPULATION WITH VISUAL IMPAIRMENT: STUDY OF 385 CASES
}

\author{
Maria Aparecida Onuki Haddad, Frederico José Correa Lobato, Marcos Wilson \\ Sampaio, and Newton Kara-José
}

Haddad MAO, Lobato FJC, Sampaio MW, Kara-José N. Pediatric and adolescent population with visual impairment: study of 385 cases. Clinics. 2006;61(3):239-46.

OBJECTIVE: To analyze data on the pediatric population attending the Ophthalmologic Clinic's Low Vision Service at the São Paulo University Medical School.

METHODS: Low vision ophthalmologic assessment, from April 1998 to December 2003, of 385 children and adolescents with mean age of 7 years; $51.7 \%$ males and $48.3 \%$ females. The main data analyzed were age, diagnosis, anatomic site of the ocular injury, visual acuity, and prescription of optical aids.

RESULTS: $45.4 \%$ were below 6 years, and 54.6\% were between 6 and 16 years. 35.5\% experienced moderate visual impairment, $26 \%$ had severe visual impairment, $8.6 \%$ had profound visual impairment, $10.6 \%$ were near blind, and $1.6 \%$ were blind. The main causes of visual impairment included congenital glaucoma (30.6\%), macular retinochoroiditis due to congenital toxoplasmosis (16.7\%), congenital cataract (12.8\%), retinal and macular inherited disorders (11.7\%), and optic atrophy (9.8\%). Among schoolage children, 52.9\% received a prescription of optical aids. The most widely used optical aids for distance were 2.8 X 26 (34.4\%); $4.2 \times 12(30.3 \%)$; and 6 X 17 (26.8\%) telescopic systems. The most frequently prescribed optical aid for near vision was the $2 \mathrm{x}$ magnifying bar (33.3\%).

CONCLUSIONS: There is a need for prevention of primary (congenital infections), secondary (congenital glaucoma and retinopathy of prematurity), and tertiary (congenital cataract) visual impairment. The prescription of optical aids for school-age children will help them perform better at school and contribute to their social inclusion.

KEYWORDS: Blindness. Low vision. Rehabilitation. Congenital glaucoma. Congenital toxoplasmosis.

\section{INTRODUCTION}

Visual impairment in childhood has an impact on motor, cognitive, and affective development. Etiological factors, age of onset, presence of other impairments, environmental aspects, and the interactions among these will determine the child's difficulties and possible delay in development. ${ }^{1}$

According to the $10^{\text {th }}$ revised International Classification of Diseases and Health-related Problems, a person has

Ophthalmology Clinic, Hospital das Clínicas, São Paulo University Medical School - São Paulo/SP, Brazil.

Email: maohaddad@uol.com.br

Received for publication on December 06, 2005.

Accepted for publication on March 21, 2006. low vision when his/her best-corrected visual acuity is between 6/18 and 3/60 (visual impairment grade categories 1 and 2), and the person is considered blind when this value falls below 3/60 (categories 3, 4, and 5 ). ${ }^{2}$

The World Health Organization (WHO) estimates that, worldwide, 140 million people have low vision and 45 million are blind. ${ }^{3}$ Visual impairment in childhood is underestimated, and its prevalence is only partially known, ${ }^{4}$ ranging from 0.3 to $1.5 / 1,000$, depending on the regional socioeconomic development (between 80 and 100 blind children per 1 million in industrialized countries and 400 blind children per 1 million in the poorest areas of the world) ${ }^{5,6}$ There are an estimated 1.5 million blind children in the world, with three fourths of this total living in the poorest areas of Asia and Africa ${ }^{5}$; of these, $40 \%$ of the cases could be avoided, either by prevention or treatment. ${ }^{6}$ The world- 
wide incidence of blindness in childhood is 500,000 new cases each year, of which $60 \%$ to $80 \%$ of the children will die before the end of the second year of life from problems related to the causes of blindness or as a consequence of it. $^{7}$

Prevention of blindness in childhood has been set as a priority by the WHO because of the reduced life expectancy of the child with visual impairment and the social, economic, and emotional repercussions. ${ }^{5,6}$

Knowledge about the profile of the pediatric population with visual impairment is essential for the effectiveness of preventive programs and for the training and rehabilitation services to fulfill patients' needs. The characteristics of visual impairment in a population vary according to the accessibility to healthcare services and sociocultural factors; an important cause of blindness in a given region may be nonsignificant for another and may vary from decade to decade. ${ }^{7}$ Temporini and Kara-José have stated that planning and implementing preventive actions in ophthalmology requires a combination of the available scientific knowledge of ophthalmologic problems with knowledge on the reality that will be the object of such actions. ${ }^{8}$

Visual rehabilitation centers have the objective of preventing sequelae of visual impairment in the individual; they try to help the individual avoid disability and to promote the development of the person's potentialities. The major goal is to integrate the person into his/her family, working environment, and society.

The Ophthalmologic Clinic's Low Vision Service at the São Paulo University Medical School provides assistance to people with low vision who are referred by other services from the Ophthalmologic Clinic. The staff working at the Low Vision Service includes ophthalmologists, educators, a physiotherapist, and a psychologist. The objectives of the Service are:

- To conduct ophthalmologic assessments of patients with low vision and to prescribe and adapt the applicable optical, nonoptical, and electronic aids;

- To guide the actions to be implemented by family, parents, teachers, and community towards an efficient use of vision; this will be based on the assessment of individual requirements for the child's global development;

- To provide orientation for the individual to recover or acquire independence and autonomy. Whenever necessary, to refer the patient to other services in visual training and rehabilitation centers.

Based on the specific low vision ophthalmologic assessment and on the stability of the ocular condition, the most suitable optical aids may be prescribed. Low vision aidsoptical, nonoptical, and electronic - aim at improving visual resolution through changes in the retinal image (magnifi- cation, displacement, filtering, or condensation) and environmental conditions. Optical aids may include spectaclemounted spheroprismatic or aspheric lenses, hand magnifiers, stand magnifiers, telemicroscopes, and telescopic systems. Once the optical aid is indicated, it is prescribed after correct orientation about its use in different situations of the patient's daily life.

The objective of this study is to present the characteristics of the pediatric population attended at the Low Vision Service from April 1998 to December 2003, concerning age, causes of visual impairment, and prescription of optical aids. It is part of a general project of the Low Vision Service to establish Brazilian standards for a number of correlated conditions. ${ }^{9-11}$

\section{METHODS}

The study included 385 children and adolescents up to 15 years of age with decreased visual responses who were referred to the unit from April 1998 to October 2003.

Following the guidelines of UNICEF, the period from 0 to 15 years was considered as childhood. ${ }^{7}$

Patients were referred from other services of the Ophthalmologic Clinic, with the following information concerning their ocular condition: best corrected visual acuity, ocular motility evaluation, refraction, biomicroscopy, fundoscopy, diagnosis, and treatment received. The follow-up at the service of origin is mantained.

The mean age of the study population was 7 years; 199 (51.7\%) were boys and $186(48.3 \%)$ were girls.

Data on age, ophthalmologic diagnosis, damaged ocular structure, best corrected visual acuity, and prescription of optical aids were assessed.

Concerning the distribution of data related to the damaged ocular structure, the protocol suggested by the WHO Program for the Prevention of Blindness was used. ${ }^{12,13}$

The visual acuity values were distributed in classes of visual response according to the WHO International Classification of Diseases and Health-related Problems-Tenth Revision $^{2}$ and the International Council of Ophthalmology. ${ }^{14}$

Optical aids for distant and near vision were assessed regarding model, magnification, and correlation with the ophthalmologic diagnosis.

\section{RESULTS}

The distribution of patients according to age is displayed in Figure 1.

Visual acuity values are shown in Table 2: 137 (35.5\%) patients had moderate visual impairment (class 1), 100 


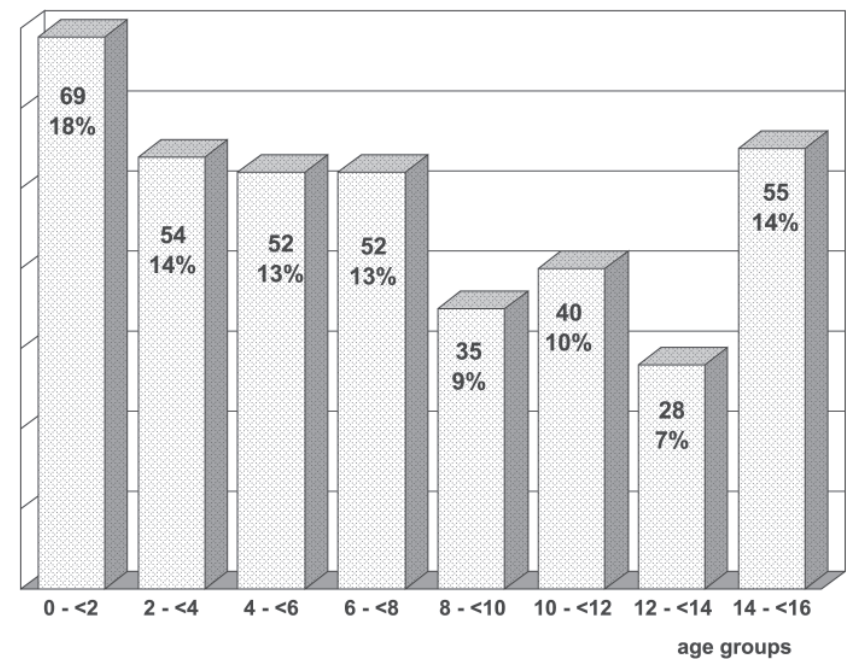

Figure 1 - Distribution of included patients according to age

(26\%) had severe visual impairment (class 2), 33 (8.6\%) had profound visual impairment, $41(10.6 \%)$ were near blind, and $6(1.6 \%)$ were blind (Table 1).

The main causes of visual impairment (Table 2).included: congenital glaucoma (30.6\%), macular retinochoroiditis due to congenital toxoplasmosis (16.6\%), congenital cataract $(12.7 \%)$, retinal and macular inherited disorders $(11.7 \%)$, and optic atrophy $(10.1 \%)$.

Concerning the location of the abnormality leading to decreased visual response, displayed in Table 3, the following sites were observed: whole globe in $32.5 \%$ of the cases: cornea, $1.3 \%$; lens, $13.3 \%$; uvea, $2.9 \%$; retina,
$33.5 \%$; optic nerve, $10.5 \%$; and $6 \%$ had no changes in ocular structures.

Optical aids were prescribed for 111 children (28.8\%). For 69 children $(17.9 \%)$, only optical aids for distant vision had been prescribed, and for 12 children (3.1\%), only optical aids for near vision. Both distant and near vision optical aids had been prescribed for 30 children (7.8\%). Among the children above 6 years $(\mathrm{n}=210), 52.9 \%$ received a prescription for optical aids.

The most widely used optical aids for distance were monocular and manual $2.8 \times 26 \mathrm{~mm}(36.4 \%) ; 4.2 \times 12$ $\mathrm{mm}$ (29\%); and $6 \times 17 \mathrm{~mm}(26.8 \%)$ telescopic systems (Table 4).

The most widely used optical aids for near vision were $2 \mathrm{X}$ magnifying bars (33.3\%) and illuminated stand magnifiers with +28 diopters (19\%) (Table 5).

With respect to ophthalmologic diagnosis, optical aids were used more frequently in cases of bilateral macular retinochoroiditis, congenital glaucoma, congenital cataract, and optic atrophy (Tables 6 and 7).

Concerning visual acuity values, $18.2 \%$ of the aids were prescribed for children with mild low vision, $40.5 \%$ for children with moderate low vision, $34.3 \%$ for children with severe low vision, and $7 \%$ for children with profound low vision (Table 8).

\section{DISCUSSION}

In developing countries, available data on visual impairment, ${ }^{4,5,15,16}$ are scarce, and do not reflect the magnitude of

Table 1 - Distribution of the pediatric population by visual acuity and classes of visual impairment

\begin{tabular}{|c|c|c|c|}
\hline Classes of visual impairment & Visual acuity & $\mathrm{n}$ & $\%$ \\
\hline Mild vision loss** & $\begin{array}{l}20 / 25<\text { VA d" } 20 / 63 \\
20 / 32,20 / 40,20 / 50,20 / 63\end{array}$ & 68 & 17.7 \\
\hline $1^{*}$ & $20 / 63<$ VA d" $20 / 160$ & & \\
\hline Moderate visual impairment** & $20 / 80,20 / 100,21 / 125,20 / 160$ & 137 & 35.5 \\
\hline $2^{*}$ & $20 / 160<$ VA d" 20/400 & & \\
\hline Severe visual impairment** & $20 / 200,20 / 250,20 / 320,20 / 400$ & 100 & 26 \\
\hline $3 *$ & $20 / 400<$ VA d" 20/1000 & & \\
\hline Profound visual impairment** & $20 / 500,20 / 630,20 / 800,20 / 1000$ & 33 & 8.6 \\
\hline $4^{*}$ & $20 / 1000<$ VA d" $20 / 2000$ & 41 & 10.6 \\
\hline \multirow[t]{3}{*}{ Near blindness ${ }^{* *}$} & $20 / 1250,20 / 1600,20 / 2000$ & 11 & 2.8 \\
\hline & perception of figures & 24 & 6.2 \\
\hline & perception of light & 6 & 1.6 \\
\hline $5^{*}$ & no perception of light & 6 & 1.6 \\
\hline \multicolumn{4}{|l|}{ Blindness** } \\
\hline Total & & 385 & 100 \\
\hline
\end{tabular}

*World Health Organization (1993). International Statistical Classification of Diseases and Health-related Problems, 10th revision

**International Council of Ophthalmology (2002). Visual Standards 
Table 2 - Distribution of the pediatric population with decreased visual response by ophthalmologic diagnosis

\begin{tabular}{|c|c|c|}
\hline & $\mathrm{n}$ & $\%$ \\
\hline Congenital glaucoma & 118 & 30.6 \\
\hline Primary & 110 & 28.6 \\
\hline Secondary to mesoectodermic dysgenesis & 8 & 2 \\
\hline $\begin{array}{l}\text { Macular retinochoroiditis due to congenital } \\
\text { toxoplasmosis }\end{array}$ & 64 & 16.6 \\
\hline \multicolumn{3}{|l|}{ DISORDERS OF THE LENS } \\
\hline Congenital cataract & 49 & 12.7 \\
\hline Treated Aphakia & 31 & 8 \\
\hline Pseudophakia & 6 & 1.6 \\
\hline Untreated & 12 & 3.2 \\
\hline Ectopic lens & 2 & 0.6 \\
\hline Marfan's syndrome & 1 & 0.3 \\
\hline Homocystinuria & 1 & 0.3 \\
\hline Optic atrophy & 39 & 10.1 \\
\hline Neonatal anoxia & 7 & 1.8 \\
\hline Congenital infections & 4 & 1 \\
\hline Postnatal infections - meningitis/ encephalitis & 5 & 1.3 \\
\hline Leber's optic neuropathy & 4 & 1 \\
\hline Craniopharyngioma & 3 & 0.8 \\
\hline Neurologic demyelinating disorders & 6 & 1.6 \\
\hline Hydrocephalus & 1 & 0.3 \\
\hline Bilateral optic neuritis & 1 & 0.3 \\
\hline No defined etiology & 8 & 2 \\
\hline Retinal and macular inherited disorders & 45 & 11.7 \\
\hline Stargardt's disease & 12 & 3.1 \\
\hline Pigmentary retinosis & 10 & 2.6 \\
\hline Albinism & 10 & 2.6 \\
\hline Cones dystrophy & 4 & 1 \\
\hline Achromatopsy & 4 & 1 \\
\hline Leber's congenital amaurosis & 4 & 1 \\
\hline Juvenile retinoschisis & 1 & 0.3 \\
\hline Ocular structures malformation & 19 & 4.9 \\
\hline Coloboma of the iris, retina, and optic nerve & 6 & 1.6 \\
\hline Microphtalmia & 6 & 1.6 \\
\hline Optic nerve hypoplasia & 2 & 0.51 \\
\hline Corneal disorders & 4 & 1 \\
\hline Nanophtalmia & 1 & 0.3 \\
\hline Retinopathy of prematurity & 12 & 3.1 \\
\hline Congenital nystagmus & 9 & 2.3 \\
\hline Detachment of retina & 7 & 1.8 \\
\hline High myopia & 4 & 1 \\
\hline Ocular toxoplasmosis & 1 & 0.3 \\
\hline Undefined etiology & 2 & 0.51 \\
\hline Brain-related visual disorder & 8 & 2 \\
\hline Neonatal anoxia & 3 & 0.8 \\
\hline Hydrocephalus & 3 & 0.8 \\
\hline S. Dandy Walker & 1 & 0.3 \\
\hline Cerebral vasculitis Juvenile rheumatoid arthritis & 1 & 0.3 \\
\hline Other forms of uveitis & 5 & 1.4 \\
\hline D. Vogt Koyanag-Harada & 1 & 0.3 \\
\hline Chronic cyclitis & 2 & 0.51 \\
\hline Juvenile rheumatoid arthritis & 1 & 0.3 \\
\hline Undefined etiology & 1 & 0.3 \\
\hline High myopia & 6 & 1.6 \\
\hline Bilateral retinoblastoma & 1 & 0.3 \\
\hline Bilateral leukoma (post-infection) & 1 & 0.3 \\
\hline TOTAL & 385 & 100 \\
\hline
\end{tabular}

Table 3 - Distribution of the pediatric population by site of the abnormality leading to decreased visual response

\begin{tabular}{lcc}
\hline $\begin{array}{l}\text { Site of the abnormality leading to } \\
\text { decreased visual response }\end{array}$ & $\mathrm{n}$ & $\mathbf{\%}$ \\
\hline Whole globe & 125 & 32.5 \\
Cornea & 5 & 1.3 \\
Lens & 51 & 13.3 \\
Uvea & 11 & 2.9 \\
Retina & 129 & 33.5 \\
Optic nerve & 41 & 10.5 \\
No injury to ocular structures & 23 & 6 \\
Total & $\mathbf{3 8 5}$ & $\mathbf{1 0 0}$ \\
\hline
\end{tabular}

Table 4 - Distribution of frequency of prescribed optical aids For far distance in the pediatric population with low vision

\begin{tabular}{lcc}
\hline OPTICAL AID FOR DISTANCE & $\mathrm{n}$ & $\%$ \\
\hline Monocular and manual telescopic system & & \\
2.5 X $23 \mathrm{~mm}$ & 2 & 2 \\
2.8 X $26 \mathrm{~mm}$ & 36 & 36.4 \\
4.2 X $12 \mathrm{~mm}$ & 30 & 20.3 \\
6 X $17 \mathrm{~mm}$ & 25 & 25.3 \\
8 X $21 \mathrm{~mm}$ & 5 & 5 \\
Spectacle-mounted binocular system $2.5 \times 20 \mathrm{~mm}$ & 1 & 1 \\
Total & $\mathbf{9 9}$ & $\mathbf{1 0 0}$ \\
\hline
\end{tabular}

Table 5 - Distribution of frequency of prescribed optical aids for near distance in the pediatric population with low vision

\begin{tabular}{lcc}
\hline OPTICAL AID FOR NEAR VISION & $\mathrm{n}$ & $\%$ \\
\hline MOUNTED ON SPECTACLES & & \\
Addition of +4.00 ED & 3 & 7 \\
Spheric-prismatic lenses +6.00 ED + 8 PD base in & 1 & 2.4 \\
Spheric-prismatic lenses +8.00 ED = 10 PD base in & 1 & 2.4 \\
Addition of +10 ED monocular & 2 & 4.8 \\
+20 aspheric diopters (monocular) & 1 & 2.4 \\
+24 aspheric diopters (monocular) & 2 & 4.8 \\
HAND MAGNIFIERS & & \\
+12 aspheric diopters & 4 & 9.5 \\
+16 aspheric diopters & 2 & 4.8 \\
+20 aspheric diopters & 2 & 4.8 \\
STAND MAGNIFIER & & \\
Bar magnifier 2X magnification & 14 & 33.3 \\
+28 aspheric diopters with light & 8 & 19 \\
38 aspheric diopters with light & 2 & 4.8 \\
Total & $\mathbf{4 2}$ & $\mathbf{1 0 0}$ \\
\hline
\end{tabular}

the problem of childhood visual impairment. ${ }^{4,5}$ Studies conducted at visual impairment assistance services may contribute to the knowledge on the local characteristics and help with planning actions, although they represent only the part of the population that had access to care,. In Latin America, studies on the causes of blindness have been conducted in schools for the blind..$^{15,16}$ In Brazil, a country of 
Table 6 - Distribution of prescribed optical aids for far distance by ophthalmologic diagnosis

\begin{tabular}{lcc}
\hline Ophthalmologic diagnosis & $\begin{array}{c}\text { Optical aids for distance } \\
\mathrm{n}\end{array}$ & $\%$ \\
\hline Bilateral macular retinochoroiditis & 31 & 31 \\
Congenital glaucoma & 21 & 21 \\
Congenital cataract & 7 & 7 \\
Optic atrophy & 7 & 7 \\
Stargardt's disease & 6 & 6 \\
Albinism & 6 & 6 \\
Cones dystrophy & 3 & 3 \\
Coloboma of the iris, choroids \& and retina & 3 & 3 \\
High myopia & 3 & 3 \\
Pigmentary retinosis & 3 & 3 \\
Achromatopsy & 2 & 2 \\
Nystagmus & 2 & 2 \\
Retinopathy of prematurity & 2 & 2 \\
Chronic cyclitis & 1 & 1 \\
Retinoblastoma & 1 & 1 \\
Nanophtalmia & 1 & 1 \\
Total & $\mathbf{9 9}$ & $\mathbf{1 0 0}$ \\
\hline
\end{tabular}

Table 7 - Distribution of prescribed optical aids for near distance by ophthalmologic diagnosis

\begin{tabular}{lcc}
\hline Ophthalmologic diagnosis & $\begin{array}{c}\text { Optical aids for near vision } \\
\mathrm{n}\end{array}$ & $\%$ \\
\hline Bilateral macular retinochoroiditis & 9 & 21.2 \\
Congenital glaucoma & 5 & 11.9 \\
Congenital cataract & 5 & 11.9 \\
Optic atrophy & 5 & 11.9 \\
Stargardt's disease & 3 & 7.1 \\
Other forms of uveitis & 2 & 4.8 \\
Detachment of retina & 2 & 4.8 \\
Corneal malformation & 2 & 4.8 \\
Pigmentary retinosis & 1 & 2.4 \\
Coloboma of the iris, choroids \& and retina & 1 & 2.4 \\
Albinism & 1 & 2.4 \\
Nanophtalmia & 1 & 2.4 \\
Cones dystrophy & 1 & 2.4 \\
Achromatopsy & 1 & 2.4 \\
Retinopathy of prematurity & 1 & 2.4 \\
Juvenile retinoschisis & 1 & 2.4 \\
Retinoblastoma & 1 & 2.4 \\
Total & $\mathbf{4 2}$ & $\mathbf{1 0 0}$ \\
\hline
\end{tabular}

Table 8 - Distribution of prescribed optical aids for far distance by class of visual impairment

\begin{tabular}{|c|c|c|c|}
\hline Classes of visual impairment & Visual acuity & $\begin{array}{l}\text { Optical aids for distant vision } \\
n\end{array}$ & $\%$ \\
\hline Mild vision loss** & $\begin{array}{l}20 / 25<\text { VA d } \bullet 20 / 63 \\
20 / 32,20 / 40,20 / 50,20 / 63\end{array}$ & 18 & 18.2 \\
\hline $\begin{array}{l}1 * \\
\text { Moderate visual impairment** }\end{array}$ & $\begin{array}{l}20 / 63<\text { VA d } \bullet 20 / 160 \\
20 / 80,20 / 100,21 / 125,20 / 160\end{array}$ & 40 & 40.5 \\
\hline $\begin{array}{l}2 * \\
\text { Severe visual impairment** }\end{array}$ & $\begin{array}{l}20 / 63<\mathrm{VA} \mathrm{d} \cdot 20 / 160 \\
20 / 160<\mathrm{VA} \mathrm{d} \cdot 20 / 40020 / 200,20 / 250,20 / 320,20 / 400\end{array}$ & 34 & 34.3 \\
\hline $\begin{array}{l}3 * \\
\text { Profound visual impairment** }\end{array}$ & $\begin{array}{l}20 / 400<\mathrm{VA} \mathrm{d} \bullet 20 / 1000 \\
20 / 500,20 / 630,20 / 800,20 / 1000\end{array}$ & 7 & 7 \\
\hline $\begin{array}{l}4^{*} \\
\text { Near blindness** }\end{array}$ & $\begin{array}{l}20 / 1000<\mathrm{VA} \mathrm{d} \cdot 20 / 2000 \\
20 / 1250,20 / 1600,20 / 2000 \\
\text { perception of figures } \\
\text { perception of light }\end{array}$ & - & - \\
\hline $\begin{array}{l}5^{*} \\
\text { Blindness** }\end{array}$ & no perception of light & - & - \\
\hline Total & & 99 & 100 \\
\hline
\end{tabular}

*World Health Organization (1993). International Statistical Classification of Diseases and Health-related Problems, 10th revision

**International Council of Ophthalmology (2002). Visual Standards

continental dimensions with diversified social, cultural, and economic characteristics, regional studies may show particular features of each area and service. Therefore, the present study aims at contributing to the recognition of the profile of the pediatric population with decreased visual response.

The main causes of decreased visual responses were retinal injuries in $33.5 \%$ of the cases, whole globe abnormalities in $32.5 \%$, lens pathology in $13.3 \%$, and optic nerve injury in $10.5 \%$. Data from developing countries indicate that corneal disorders account for $20 \%$ to $50 \%$ of the cases of blindness in childhood ${ }^{5,6,7,15}$; in the present study, we found a prevalence of $1.3 \%$ of corneal disorders, the same as observed in industrialized countries (less than $2 \%$ ). ${ }^{6}$ This discrepancy may be explained by the higher frequency of corneal injuries secondary to vitamin A deficiency and infections in African and Asian countries, where they account for up to $50 \%$ of the cases of blindness, and in Bolivia, 
the Dominican Republic, and Peru, where they account for $20 \% .^{15,16}$

In the present study, the major cause of visual impairment was congenital glaucoma, due to the referral of patients to the Congenital Glaucoma Service of the Ophthalmologic Clinic. International data indicate that congenital glaucoma accounts for $6 \%$ of the cases of blindness in childhood worldwide. ${ }^{6}$ Visual loss may be also secondary to optic nerve injury, corneal opacities, cataract, and amblyopia. ${ }^{1,18}$ The possibility of a better visual resolution with the help of optical, nonoptical, and electronic aids should be considered as well in these cases. ${ }^{19}$

Macular retinochoroiditis due to congenital toxoplasmosis was the second most frequent diagnosis (15.8\%). Kara-José ${ }^{20}$ and Carvalho ${ }^{21}$ reported congenital toxoplasmosis as the major cause of visual impairment in the pediatric population seen at the Low Vision Department at the State University of Campinas. Tartarella ${ }^{22}$ indicated infections as the main etiology among the patients seen at the Early Visual Stimulation Department of Hospital São Paulo, 30\% from toxoplasmosis-related ocular damage; and Haddad ${ }^{23}$ observed this etiology in $11 \%$ of the cases seen at the Brazilian Association for the Visually Impaired People - Laramara.

Congenital cataract was found, in $12.7 \%$ of the cases in agreement with other local reports, ${ }^{21-24}$. Cataract accounts for $5 \%$ to $20 \%$ of the cases of blindness in childhood, ${ }^{7,25}$ and children with untreated cataract represent $10 \%$ of those attending schools for the blind in developing countries. ${ }^{7}$ In the present study, surgery was not indicated in $24.5 \%$ of the cataract cases, while $75.5 \%$ had been treated surgically. In $12.2 \%$ of these cases, an intraocular lens implantation was performed. Concerning the etiology of congenital cataract, one third is considered to be idiopathic, $50 \%$ are due to genetic mutations, ${ }^{15,18}$ and, in our context, rubella is an evident cause. ${ }^{7,15}$ According to Foster (1992), rubella is more relevant in countries where nutritional factors have been eradicated but where there is no effective immunization program for school-age girls.

Optic nerve atrophy was observed in $10.1 \%$ of the cases. Several reports have described the same cause in studies conducted in developed countries, 5,19,26,27 where it appears with increasing frequency. ${ }^{7}$ Faye (1984) found optic atrophy to be the major cause of visual impairment in patients aged 0 to 19 years seen at the New York Lighthouse Low Vision Service, from 1979 to 1983. It is difficult to isolate the cause of optic atrophy, particularly in developing countries where medical records are incomplete. Several factors might contribute, including heredity, exposure to toxic substances during pregnancy, hypoxia, trauma, and perinatal infections. ${ }^{7}$ In this study, we found neonatal anoxia to be the major cause $(10.1 \%)$ of optic atrophy in the pediatric population studied.

Among inherited disorders of the retina, retinitis pigmentosa and Stargardt's disease were most frequently observed. The progressive nature of several inherited disorders of the retina should be considered, and referral to visual rehabilitation services should be as early as possible.

Retinopathy of prematurity (ROP) was observed in $3.1 \%$ of the cases, and is considered a frequent cause of visual impairment in developing countries. ${ }^{7,16,18,27}$ Technological advances have increased survival rates in very low birth weight preterm newborns, resulting in a higher incidence of ROP. ${ }^{7,15,16}$ In Latin American countries such as Argentina, Cuba, and Paraguay, ROP accounts for one third to one half of the cases of blindness or profound low vision. ${ }^{15}$ In the United States, its frequency is low, between $8 \%$ to $19 \%$ of the cases of blindness, thanks to better neonatal intensive care. ${ }^{12}$ Catalano and Nelson ${ }^{18}$ consider that $90 \%$ of the cases of ROP resolve spontaneously, with minimal remaining damage and visual difficulties. A multicenter study ${ }^{1,26}$ revealed that $65.8 \%$ of the cases of retinopathy of prematurity had no harmful effect on the visual function. Therefore, the cases observed in the present study correspond only to a part of the cases of ROP - ie, those with impaired visual response.

Referral to the Low Vision Service occurred similarly in all age groups. Early detection and attention to low vision is essential for the baby's global development, for the adaptation of optical aids in preschool and school-age children, and for family support, this being the major factor for the child's global development. ${ }^{28}$ The school-age group observed represented $52.9 \%$ of the study population. Visual difficulties may become more evident with school activities; consequently, teachers and school staff have a critical role in the detection of visual problems, referral to specialized medical care, and in the development of actions to integrate the child into the educational system.

Moderate and severe visual impairment were the most frequent classes of visual loss and good results may be achieved when retinal image magnification aids are indicated. ${ }^{14,28,29}$ Accordingly, we observed that $40.5 \%$ and $34.3 \%$ of optical aids for distance were prescribed to patients with moderate and severe visual impairment, respectively.

Functional characteristics of the patient, the type of tasks he or she wants to perform, neuropsychomotor development, and individual needs should be considered in the choice of the low vision aids to be used. ${ }^{19,28,29}$ In the present study, $28.8 \%$ of the patients were prescribed optical aids. If we consider only the school-age group, between 6 and 15 years, $52.9 \%$ of them received such prescriptions. 
Optical aids for distance were the most frequently used. In children, manual and monocular telescopic systems are usually indicated. ${ }^{28}$ Daily tasks, such as reading blackboards, may be performed with a visual acuity of 20/40. ${ }^{19,30}$ Therefore, telescopic systems of low magnification power, from $2 \mathrm{X}$ to $4 \mathrm{X}$, may be effective when used for visual acuity up to $20 / 125 .{ }^{28}$ Telescopic systems of 2.8 X $20 \mathrm{~mm}$, $4.2 \times 12 \mathrm{~mm}$, and $6 \times 17 \mathrm{~mm}$ were the most frequently used $(36.4 \%, 30.3 \%$, and $25.3 \%$, respectively).

The child's accommodation allows for easy achievement of retinal image magnification by decreasing the eyeobject distance, so that optical aids for near vision tend to be used less frequently or to be of low dioptric power. In the present study, the most frequently used optical aid for near vision was the $2 \mathrm{x}$ magnifying bar. We should note that in some children with low vision, accommodation develops more slowly, ${ }^{32}$ justifying the use of optical correction or aids for near-vision image magnification.

Concerning ophthalmic diagnosis, optical aids were more often prescribed in cases of bilateral macular retinochoroiditis due to congenital toxoplasmosis, in which decreased visual acuity and central and/or paracentral visual field defects, with variable location and density of scotomas, depending on the extent and deepness of macular involvement are present. In general, the peripheral field is preserved, allowing good results to be achieved with optical aids for retinal image magnification. ${ }^{33}$
Family and educators should be oriented about visual function, about ocular disorders and their prognosis, and about the use of appropriate low vision aids. Cooperation between the ophthalmologist, the family, and the community is essential to ensure compliance to the orientations, thus contributing to a better effectiveness of the actions aimed at socially integrating the child with visual impairment. ${ }^{34}$

Based on the present study, we conclude the following: - The main causes of visual impairment in childhood, in this study, were congenital glaucoma and bilateral macular retinochoroiditis due to congenital toxoplasmosis.

- Retinal causes of visual impairment were more frequent.

- Moderate and severe visual impairment were the most frequently observed classes of visual impairment.

- Among school-age children, 52.9\% received a prescription of optical aids.

- Regional studies should be conducted for a better understanding of the characteristics of the pediatric population with visual impairment.

- Prenatal factors (such as rubella and toxoplasmosis) and perinatal factors (such as perinatal hypoxia and prematurity) have an important role in determining visual deficiency in our setting. Actions towards primary, secondary, and tertiary prevention should be emphasized to reduce avoidable causes of blindness and low vision.

\section{RESUMO}

Haddad MAO, Lobato FJC, Sampaio MW, Kara-José N. População infantil com deficiência visual: estudo de 385 casos. Clinics. 2006;61(3):239-46.

OBJETIVO: Analisar as características da população infantil atendida no Serviço de Visão Subnormal da Clínica Oftalmológica do Hospital das Clínicas da Faculdade de Medicina da Universidade de São Paulo.

MÉTODOS: Avaliação oftalmológica de 385 crianças e adolescentes, de abril de 1998 a dezembro de 2003, com idade média de 7 anos; $51,7 \%$ do sexo masculino e 48,3\% do sexo feminino. Idade, diagnóstico oftalmológico, localização anatômica da lesão ocular, acuidade visual e auxílios ópticos adaptados foram observados.

RESULTADOS: $45,4 \%$ tinham idade inferior a 6 anos e $54,6 \%$ tinham entre 6 e 16 anos de idade. $35,5 \%$ apresentavam baixa visão moderada, $26 \%$ baixa visão grave, $8,6 \%$ baixa visão profunda, $10,6 \%$ quase cegueira e 1,6\% cegueira. As principais causas da deficiência visual foram: glaucoma congênito (30,6\%), retinocoroidite macular por toxoplasmose congênita $(16,7 \%)$, catarata congênita $(12,8 \%)$, doenças hereditárias da retina e mácula $(11,7 \%)$ e atrofia óptica $(9,8 \%)$. Na população de crianças em idade escolar, 52,9\% tiveram auxílios ópticos adaptados. Os auxílios ópticos para longe mais utilizados foram os sistemas telescópicos de 2,8X 26 (34,4\%), de 4,2 X 12 (30,3\%) e de 6 X 17 (26,8\%). O auxílio óptico para perto mais adaptado foi a barra de ampliação de $2 \mathrm{X}$ de aumento $(33,3 \%)$. CONCLUSÕES: Necessidade de prevenção primária (infecções congênitas), prevenção secundária (glaucoma congênito e retinopatia da prematuridade) e prevenção terciária (catarata congênita). A adaptação de auxílios ópticos nas crianças em idade escolar irá colaborar para o seu maior desempenho escolar e sua inclusão social.

UNITERMOS: Cegueira. Baixa visão. Reabilitação. Glaucoma congênito. Toxoplasmose congênita. 
1. Teplin SU. Visual impairment in infants and young children. Inf Young Children. 1995;8:18-51.

2. Organização Mundial da Saúde. Classificação Internacional de Doenças e Problemas Relacionadas à Saúde - Décima Revisão. São Paulo:Edusp; 1993.

3. World Health Organization. Blindness and visual disability: part 3: other leading causes worldwide. Geneve, World Health Organization, 1997; pt 3 of 7, 3 p. (WHO fact sheet, n.144)

4. World Health Organization. Programme for the Prevention of Blindness - Management of low vision in children-Report of a WHO Consultation. Bangkok, 1992; 48 p. (WHO/PBL/93.27)

5. Gilbert C, Foster A. Childhood blindness in the context of vision 2020the right to sight. Bull World Health Organ. 2001;79:227-32.

6. Gilbert C, Foster A. Blindness in children: control priorities and research opportunities. Br J Ophthalmol. 2001;85:1025-7.

7. Foster A, Gilbert C. Epidemiology of childhood blindness. Eye. 1992;6:173-6.

8. Temporini ER, Kara-José N. Níveis de Prevenção de problemas oftalmológicos: propostas de investigação. Arq Bras Oftal. 1995;58:18992.

9. Bonanomi, MTBC, Susanna Jr. R. Intravitreal triamcinolone acetonide as adjunctive treatment for neovascular glaucoma. Clinics. 2005;60:347350.

10. Avakian A, Temporini ER, Kara-José N. Second eye cataract surgery: Perceptions of a population assisted at a university hospital. Clinics. 2005;60:401-406.

11. Oliveira R de SC de S, Temporini ER, Kara-José N, Carricondo PC, Kara-José AC. Perceptions of patients about cataract. Clinics. 2005;60:455-460.

12. Gilbert C, Foster A, Négrel AD, Thylefors B. Childhood blindness: a new form for recording causes of visual loss in children. Bulletin of World Health Organization. 1993;71:485-9.

13. Thylefors B. A simplified methodology for the assessment of blindness and its main causes. Wld Hlth Statist Quart. 1987;40:129-41.

14. Colenbrander A. Visual standards - aspects and ranges of vision loss. International Council of Ophthalmology Report. Sydney, 2002. 33 p.

15. Muñoz B, West SK. Blindness and visual impairment in the Americas and the Caribbean. Br J Ophthalmol. 2002;86:498-504.

16. Gilbert C, Canovas R, Canovas RK, Foster A. Causes of blindness and severe visual impairment in children in Chile. Dev Med Child Neurol. 1994;36:326-33

17. Brito PR, Veitzman S. Causas de cegueira e baixa visão. Arq Bras Oftal. 2000;63:49-54.

18. Catalano RA, Nelson LB. Pediatric ophthalmology. Norwalk: Appleton \& Lange; 1994.
19. Faye EE. Clinical low vision. 2nd ed. Boston: Little, Brown and Company; 1984.

20. Kara_José N, Carvalho KMM, Pereira VL, Venturini NHB, Gasparetto MEFR, Gushiken MT. Estudo retrospectivo dos primeiros 140 casos atendidos na Clínica de Visão Subnormal do Hospital de Clínicas da Unicamp. Arq Bras Oftalmol. 1998;51:65.

21. Carvalho KMM, Minguini N, Moreira Filho D, Kara-José N. Characteristics of a pediatric low-vision population. J Pediatr Ophthalmol Strabismus. 1996;35:162-5.

22. Tartarella MB, Nakano K, Castro CTM, Martins APM. Visão Subnormal em crianças. Arq Bras Oftalmol. 1991;54:221-4.

23. Haddad MAO, Sei M, Braga AP, Sampaio MW, Kara-José N. Causes of visual impairment in childhood and adolescence: a retrospective study of 1917 cases. In: Stuen C, Arditi A, Horowitz A, Lang MA, Rosenthal B, Seidman KR. Vision rehabilitation. Assessment, intervention and outcomes. New York: Swets \& Zeitlinger; 2000. p. 371-5.

24. Kitadai SPS, Bonomo PP. Catarata Congênita: frequência etiológica. Arq Bras Oftal. 1994;57:404-6.

25. Tartarella MB, Kawakami LT, Scarpi MJ, Hayashi S, Bonomo PPO Aspectos cirúrgicos em catarata congênita. Arq Bras Oftal. 1995;58:248.

26. Viisola M. Statistics on children and visual impairments. New York: Lighthouse International; 1999.

27. Blomé J, Tornqvist K. Visual impairment in Swedish children. Acta Ophthalmol Scand. 1997;75:681-7.

28. Haddad MAO, Sampaio MW, Kara-José N. Baixa visão na infância. Manual Básico para oftalmologistas. São Paulo: Laramara; 2001.

29. Sampaio MW, Haddad MAO, Kara-José N. Auxílios para baixa visão. São Paulo: Laramara; 2001.

30. Lopez JMV. Apuntes Sobre Rehabilitacion Visual. Madrid: Organizacion Nacional de Ciegos Españoles; 1994.

31. Faye EE. El enfermo com deficit visual. ed. espanhola. Barcelona: Editorial Cientifico-Médica; 1972.

32. Lindsted E. Acommodation in the visually impaired child. In: WOO G. Low vision-principles and applications. Waterloo: Springer-Verlag; 1986. p. 425-35.

33. Haddad MAO, Braga AP, Sei M, et al. Low cost telescopic system: its effectiveness in cases of macular retinochoroiditis due to congenital toxoplasmosis. In: Stuen C, Arditi A, Horowitz A, Lang MA, Rosenthal B, Seidman KR. Vision rehabilitation. Assessment, intervention and outcomes. New York: Swets \& Zeitlinger; 2000. p. 195-9.

34. Gasparetto MERF, Temporini ER, Carvalho KMM, Kara-José N. O aluno portador de visão subnormal na escola regular: desafio para o professor? Arq Bras Oftal. 2001;64:45-51. 